JEMAP: Jurnal Ekonomi, Manajemen, Akuntansi, dan Perpajakan

\title{
Faktor- Faktor Yang Mempengaruhi Keputusan Pembelian Konsumen di Virgin Cake \& Bakery Tlogosari Semarang
}

\author{
Jong Stefanus, Dwi Hayu Agustini \\ email: Jong18d30063@student.unika.ac.id \\ Universitas Katolik Soegijapranata
}

\begin{abstract}
This research aimed to know what factors and which one was the most effective in influencing the consumer purchasing decision in Virgin Cake \& Bakery at Tlogosari Semarang. The sample number of research using purposive sampling was 70 respondents. Analysis conducted was descriptive. Result of analysis showed that there 22 factors affecting consumer purchasing decision. The factors were grouped in 5 factors namely product, service, price, location and information source.
\end{abstract}

Keywords: product, service, price, consumer purchasing decision

\section{PENDAHULUAN}

\section{Latar Belakang Masalah}

Makan merupakan kebutuhan utama bagi manusia. Masyarakat sekarang lebih memilih mengkonsumsi makanan yang lebih praktis seperti roti. Roti lebih praktis karena roti mudah didapat. Tidak sedikit pula konsumen yang rela mengeluarkan biaya lebih untuk sebuah roti yang menurut mereka sesuai dengan seleranya, sehingga dapat disimpulkan produk yang dijual mempengaruhi keputusan pembelian konsumen pada sebuah toko roti (Kotler dan Armstrong, 2001). Besarnya kebutuhan akan permintaan roti mengakibatkan semakin banyaknya perusahaan baru yang masuk, sehingga persaingan dalam industri roti semakin tinggi.

Hal ini juga terjadi di daerah Telogosari Semarang. Awalnya di daerah tersebut terdapat sebuah toko roti yang bernama Virgin. Virgin pada saat itu berhasil menguasai pasar roti yang ada di daerah Tlogosari dan sekitarnya disebabkan karena memiliki lokasi yang berada sangat dekat dengan pintu masuk Telogosari, lebih mudah ditemukan oleh para konsumen. Akan tetapi adanya peluang bisnis yang besar menyebabkan munculnya beberapa toko roti baru seperti 
JEMAP: Jurnal Ekonomi, Manajemen, Akuntansi, dan Perpajakan ISSN: 2622-612X (Media Online) | Vol.2 | No.2 | Oktober 2019

toko roti Swiss Deli, toko roti Tifa Bakery, dan toko roti Allamanda. Hal ini mengakibatkan meningkatnya persaingan di tempat tersebut. Mengingat di jalan Tlogosari Semarang memang memiliki beberapa toko roti yang letaknya tidak terlalu jauh satu sama lain, hal ini dapat di lihat pada table 1.

Tabel 1. Lokasi Toko Roti Sekitar Tlogosari

\begin{tabular}{|c|c|}
\hline Toko Roti & Alamat \\
\hline Virgin Cake \& Bakery & J1. Parangkusumo Raya no. 16-18 \\
Tlogosari, Semarang
\end{tabular}

Sumber : Data Primer, 2017

Jika diamati ada sebuah fenomena yang cukup menarik mengenai jumlah konsumen yang datang di toko roti Virgin dan beberapa toko roti yang ada di daerah Tlogosari. Toko roti Virgin memiliki konsumen yang jauh lebih banyak (signifikan) dibanding toko roti lainnya, hal ini bisa dilihat dari jumlah antrian kasir dan jumlah kendaraan yang ada di parkiran toko roti Virgin, padahal jarak antara toko roti Virgin dan toko roti lainnya tidak berjauhan. Faktor keputusan pembelian menurut Kotler (2005) terkait faktor pribadi, sosial, dan situasional. Faktor pribadi meliputi persepsi, motivasi, pembelajaran, sikap, usia dan gaya hidup. Sedangkan budaya, kelas sosial, dan kelompok merupakan bagian dari faktor sosial. Sedangkan untuk faktor situasional seperti pengaruh waktu, fasilitas, dan kondisi konsumen yang berbeda. Dengan kata lain keputusan pembelian dapat di pengaruhi oleh banyak faktor. Alasan atau penyebab mengingkatnya jumlah konsumen di toko roti Virgin akan menunjukan faktor-faktor yang di pertimbangkan konsumen dalam melakukan pembelian roti di toko roti Virgin Tlogosari Semarang. Dengan demikian, dapat dirumuskan beberapa masalah penelitian sebagai berikut apa saja faktor yang mempengaruhi keputusan pembelian konsumen Virgin? Faktor apa yang paling berpengaruh terhadap keputusan pembelian konsumen Virgin? 
JEMAP: Jurnal Ekonomi, Manajemen, Akuntansi, dan Perpajakan

\section{Tujuan dan Manfaat Penelitian}

Tujuan Penelitian ini untuk mengetahui fakor-faktor yang mempengaruhi keputusan pembelian konsumen di toko roti Virgin Tlogosari Semarang. Manfat penelitian ini adalah hasil penelitian ini dapat digunakan sebagai referensi untuk peneliti lain yang akan melakukan penelitian sejenis. Bagi pengusaha toko roti dapat dimanfaatkan untuk menetapkan strategi pemasaran untuk meningkatkan pembelian pada toko roti mereka.

\section{TINJAUAN PUSTAKA}

\section{Keputusan Pembelian}

Pengambilan keputusan konsumen merupakan proses yang mengkombinasikan pengetahuan untuk mengevaluasi dua atau alternatif perilaku dalam membeli. Menurut Peter dan Olson (1999) proses pengambilan keputusan pembelian dianggap sebagai suatu penyelesaian masalah yang mempunyai tujuan akhir yang jelas yaitu terpenuhinya kebutuhan konsumen. Terdapat beberapa langkah dalam hal pengambilan keputusan pembelian suatu produk. Proses pengambilan keputusan dimulai ketika pembeli menyadari suatu masalah atau kebutuhan yang mereka alami. Sedangkan pengenalan masalah dapat dipicu oleh rangsangan yang berasal dari diri mereka sendiri (rasa lapar, haus) atau rangsangan dari luar, contohnya faktor lingkungan. Selanjutnya pencarian informasi, evaluasi alternatif, mengambil sikap, dan melakukan pembelian. Setelah itu konsumen akan melakukan evaluasi atas pembeliannya dan mengambil keputusan membeli ulang atau tidak. Demikian juga apabila konsumen puas maka akan merekomendasikan ke teman-temannya.

\section{Faktor- Faktor Dalam Pengambilan Keputusam}

Dalam pengambilan keputusan konsumen memandang produk sebagai suatu paket atribut produk dimana atribut-atribut tersebut nantinya yang akan menjadi pertimbangan dalam pengabilan keputusan. Konsumen akan menentukan atribut- atribut produk yang mana yang menurut pertimbangan mereka relevan, dan 
JEMAP: Jurnal Ekonomi, Manajemen, Akuntansi, dan Perpajakan

mereka akan manaruh perhatian besar pada atribut yang sesuai dengan kebutuhan mereka (Kotler dan Armstrong, 2001).

Menurut Tjiptono yang dikutip dalam Akbar (2013) atribut produk adalah unsur-unsur produk yang dipandang penting oleh konsumen dan dijadikan dasar pengambilan keputusan. Atribut Produk meliputi merek, kemasan, pemberian label, jaminan(garansi), pelayanan, dan sebagainya. Merek adalah nama, istilah, simbul atau logo yang menunjukan identitas dari suatu produk dan untuk membedakan produk satu dengan produk yang lain. Tujuan dari merek adalah: Identitas produk, untuk membedakan produk suatu prusahaan dan produk perusahaan lain. Alat promosi atau daya tarik produk untuk membina citra, untuk mengendalikan pasar. Kemasan adalalah wadah atau pembungkus suatu produk. Tujuan dari kemasan adalah: sebagai pelindung isi misalnya menghindari dari kerusakan, kehilangan, berkurangnya kadar isi. Untuk memberikan kemudahan dalam kegunaan, misalnya agar tidak tumpah atau jatuh, sebagai sarana pemegang produk. Pemberian label. Label adalah bagian dari suatu produk yang menyampaikan informasi mengenai produk dan penjual. Sebuah label bisa merupakan bagian dari kemasan, atau bisa pula merupakan etiket (tanda pengenal) yang dicantelkan pada produk.

Jaminan adalah janis yang merupakan kewajiban produsen atas produknya kepada konsumen, dimana para konsumen diberi ganti rugi bila produk ternyata tidak bisa berfungsi sebagaimana yang diharapkan atau dijanjikan. Jaminan meliputi kualitas produk, reparasi, ganti rugi, dan sebagainya.

Layanan adalah kegiatan atau serangkaian kegiatan yang berlangsung dalam interaksi frekuensi atau mesin fisik yang memberikan kepuasan konsumen. Produk apapun tidak terlepas dari unsur jasa atau layanan, baik itu jasa sebagai produk inti (jasa murni) maupun jasa sebagai pelengkap. Produk inti umumnya sangat bervariasi antara tipe bisnis yang satu dengan tipe yang lain.

Menurut Kotler dalam Saidani dan Ramadhan (2013) atribut produk meliputi kualitas produk, fitur produk, desain atau rancangan produk. Kualitas produk berhubungan degan kinerja dari produk dan jasa. Dalam kata lain kualitas produk bisa di artikan kebebasan dari cacat, karena semakin berkualitas produk 
maka semakin kecil kecacatan yang ada pada produk tersebut. Oleh karena itu kualitas produk berhubungan dengan keuasan pelanggan terhadap produk tersebut. Fitur produk sebuah produk dapat ditawarkan dengan beraneka macam fitur. Perusahaan dapat menciptakan model dengan tingkat yang lebih tinggi dengan menambah beberapa fitur. Desain produk bisa di katakan pengambilan sebuah produk, desain produk juga berpengaruh pada manfaatnya dan juga bisa meningkatkan daya jual produk.

Selain atribut produk, harga dan lokasi juga dapat mempengaruhi keputusan pembelian konsumen. Hal ini sesuai dengan Ferdinand yang dikutip dalam Arianto (2013) bahwa harga merupakan salah satu variabel penting dalam pemasaran di mana harga dapat mempengaruhi keputusan untuk membeli suatu produk. Sedangkan menurut Utami (2014) lokasi adalah faktor penting dalam pemilihan toko oleh konsumen. Menurut penelitian Septiyaningsih, Putra \& Wrasiati (2016), ada beberapa faktor yang mempengaruhi pembelian konsumen terhadap produk roti, diantaranya :

Tabel 2 Faktor Pembelian Konsumen terhadap Produk Roti

\begin{tabular}{|l|l|}
\hline \multicolumn{1}{|c|}{ Variabel } & \multicolumn{1}{c|}{ Deskripsi } \\
\hline Rasa & Rasa roti yang dibeli responden \\
\hline Tekstur & Tekstur roti yang dibeli responden \\
\hline Informasi kandungan gizi & Informasi kandungan gizi pada roti \\
\hline Informasi zat pengawet & $\begin{array}{l}\text { Informasi ada tidaknya tambahan zat pengawet pada } \\
\text { roti }\end{array}$ \\
\hline Informasi halal & Adanya informasi halal dan tidak pada roti \\
\hline Pengemasan & Pengemasan yang rapi \\
\hline Tanggal kadaluarsa & Tanggal kadaluarsa yang dicantumkan dalam kemasan \\
\hline Harga & Harga roti yang dibeli responden \\
\hline Lokasi & Lokasi penjualan yang terjangkau oleh konsumen \\
\hline Distribusi produk & Pengiriman produk yang tepat waktu \\
\hline Pelayanan & Pelayanan yang diberikan kepada konsumen \\
\hline Iklan/Sosialisasi/Promosi & Iklan/sosialisasi/promosi produk kepada konsumen \\
\hline
\end{tabular}

Sumber : Hasil Penelitian Septiyaningsih, Putra \& Wrasiati (2016)

Menurut Kotler dan Amstrong ( dalam Antony \& Jolanda, 2016), bahwa bauran pemasaran (4P) yang dilakukan perusahaan dapat digunakan sebagai hal untuk mempengaruhi konsumen Adapun penjelasannya sebagai berikut : Product 
JEMAP: Jurnal Ekonomi, Manajemen, Akuntansi, dan Perpajakan

(Produk). Atribut produk yang dapt digunakan untuk mempengaruhi keputusan pembelian menurut Essinger \& Wylie (Antony \& Jolanda, 2016), membagi produk khususnya makanan ke dalam beberapa kategori, diantaranya kualitas dalam hal rasa, kuantitas, variasi produk, kebersihan dan inovasi. Price atau Harga merupakan bagian yang penting dalam bauran pemasaran jasa atau produk, karena penetapan harga dapat memberikan penghasilan bagi bisnis. Adapun harga yang dapat mempengaruhi konsumen dalam membeli produk adalah harga yang terjangkau secara finansial oleh semua pangsa pasar konsumen dan sesai dengan kualitas produk yang diperolehnya. Place (Lokasi). Adapun faktor lokasi yang mempengaruhi konsumen ingin membeli produk tertentu yaitu tempat penjualan yang terjangkau dan tersedia bagi konsumen sasaran. Promotion (Promosi), bentuk promosi yang dapat mempengaruhi konsumen untuk membeli suatu produk yaitu promosi yang menggunakan segala bentuk komunikasi dalam menginformasikan, membujuk atau mengingatkan konsumen tentang produk yang dihasilkan.

Tabel 3 Penelitian Terdahulu

\begin{tabular}{|l|l|l|l|}
\hline \multicolumn{1}{|c|}{ Judul Penelitian } & \multicolumn{1}{c|}{$\begin{array}{c}\text { Nama } \\
\text { Penelitian }\end{array}$} & Metode Penelitian & \multicolumn{2}{c|}{ Hasil } \\
\hline Pengaruh Produk dan & Santri Zulaicha & 1. Populasi : & Ada pengaruh \\
Harga terhadap & \& Rusda Irawati & Konsumen & yang signifikan \\
Keputusan Pembelian & & Morning Bakery & antara variable \\
Konsumen di Morning & & yang pernah & produk dan harga \\
Bakery Batam (2016) & & membeli produk & secara simultan \\
& & 2. Sampel : 400 & terhadap \\
& & frekuensi & keputusan \\
& & 3. Teknik sampling & pembelian \\
& & kurposive & konsumen \\
& & sampling & \\
& & 4. Metode & \\
& & pengumpulan \\
& & data : observasi, & \\
& & wawancara, & \\
& & kuesioner & \\
& & 5. Analisis data : & \\
& & Regresi linear & \\
& & berganda & \\
\hline
\end{tabular}


JEMAP: Jurnal Ekonomi, Manajemen, Akuntansi, dan Perpajakan

\begin{tabular}{|c|c|c|c|}
\hline Judul Penelitian & $\begin{array}{c}\text { Nama } \\
\text { Penelitian }\end{array}$ & Metode Penelitian & Hasil \\
\hline $\begin{array}{l}\text { Analisis Faktor yang } \\
\text { Mempengaruhi } \\
\text { Konsumen dalam } \\
\text { Pengambilan Keputusan } \\
\text { Pembelian Produk Air } \\
\text { Minum Merk AQUA } \\
(2016)\end{array}$ & $\begin{array}{l}\text { M. Dian } \\
\text { Ruhamak }\end{array}$ & $\begin{array}{l}\text { 1. Populasi : } \\
\text { Konsumen } \\
\text { Morning Bakery } \\
\text { yang pernah } \\
\text { membeli produk } \\
\text { 2. Sampel : } 40 \\
\text { frekuensi } \\
\text { 3. Teknik sampling } \\
\text { : accidental } \\
\text { sampling } \\
\text { 4. Metode } \\
\text { pengumpulan } \\
\text { data : observasi, } \\
\text { wawancara, } \\
\text { kuesioner } \\
\text { 5. Analisis data : } \\
\text { Regresi linear } \\
\text { berganda }\end{array}$ & $\begin{array}{l}\text { Bahwa faktor } \\
\text { budaya, sosial, } \\
\text { pribadi dan } \\
\text { psikologis secara } \\
\text { bersama-sama } \\
\text { mempunyai } \\
\text { pengaruh } \\
\text { bermakna } \\
\text { terhadap } \\
\text { keputusan } \\
\text { pembelian produk }\end{array}$ \\
\hline $\begin{array}{l}\text { Analisis Faktor-Faktor } \\
\text { yang Mempengaruhi } \\
\text { Keputusan Pembelian } \\
\text { Produk Roti "Bapak } \\
\text { Bakery" (2016) }\end{array}$ & $\begin{array}{l}\text { Putu Mutia } \\
\text { Septyaningsih, } \\
\text { G.P Ganda } \\
\text { Putra, Luh Putu } \\
\text { Wrasiati }\end{array}$ & $\begin{array}{l}\text { 1. Populasi : } \\
\text { Konsumen } \\
\text { Morning Bakery } \\
\text { yang pernah } \\
\text { membeli produk } \\
\text { 2. Sampel : } 110 \\
\text { frekuensi } \\
\text { 3. Teknik sampling } \\
\text { : accidental } \\
\text { sampling } \\
\text { 4. Metode } \\
\text { pengumpulan } \\
\text { data : observasi, } \\
\text { wawancara, } \\
\text { kuesioner } \\
\text { 5. Analisis data : } \\
\text { Analisis faktor }\end{array}$ & $\begin{array}{l}\text { Variabel } \\
\text { variabel yang } \\
\text { membentuk } \\
\text { faktor }- \text { faktor } \\
\text { yang } \\
\text { mempengaruhi } \\
\text { keputusan } \\
\text { pembelian } \\
\text { konsumen yaitu : } \\
\text { 1. Variabel rasa, } \\
\text { harga, tekstur, } \\
\text { lokasi dan } \\
\text { distribusi } \\
\text { produk. } \\
\text { 2. Pelayanan } \\
\text { bapak bakery, } \\
\text { tanggal } \\
\text { kadaluarsa, } \\
\text { kandungan } \\
\text { zat pengawet } \\
\text { dan informasi } \\
\text { kandungan } \\
\text { gizi. } \\
\text { 3. Pengemasan, } \\
\text { informasi } \\
\text { halal dan } \\
\text { iklandi } \\
\text { media. }\end{array}$ \\
\hline
\end{tabular}


JEMAP: Jurnal Ekonomi, Manajemen, Akuntansi, dan Perpajakan ISSN: 2622-612X (Media Online) | Vol.2 | No.2 | Oktober 2019

\section{Kerangka Pikir Penelitian}

Berdasarkan tujuan penelitian dan teori- teori yang terkait dengan penelitian ini maka tersaji kerangka pikir sebagai berikut. Dari keputusan pembelian konsumen maka peneliti akan mencari tahu apa saja faktor- faktor yang mempengaruhi keputusan pembelian. Setelah mengetahui apa saja faktor- faktornya yang mempengaruhi keputusan pembelian, maka langkah selanjutnya adalah menganalisis fakto-faktor tersebut untuk mengetahui faktor manakah yang paling berpengaruh terhadap keputusan pembelian konsumen dengan melihat freksuensi tetinggi.

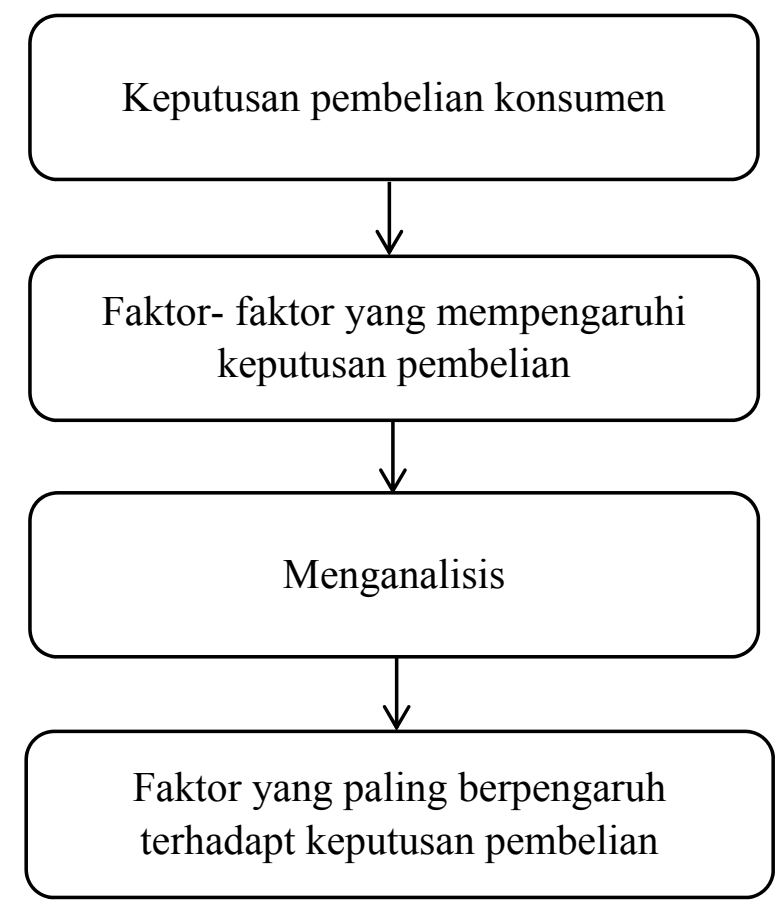

Gambar 1 Kerangka Pikir

\section{Definisi Operasional}

Keputusan pembelian konsumen adalah tindakan yang diambil konsumen setelah mengevaluasi informasi-informasi suatu produk. Indikatornya: Jumlah rata-rata yang di beli dalam setiap kali pembelian; Jumlah varian yang dibeli.

Faktor-faktor yang mempengaruhi keputusan pembelian adalah hal-hal yang dipertimbangkan konsumen untuk memilih suatu produk. Menganalisis adalah 
JEMAP: Jurnal Ekonomi, Manajemen, Akuntansi, dan Perpajakan

melakukan pemeriksaan mendalam pada suatu persoalan untuk memperoleh suatu hasil.

Faktor yang paling berpengaruh terhadap keputusan pembelian adalah hal yang paling banyak dijadikan pertimbangan konsumen dalam membeli sebuah produk. Indikatornya: Frekuensi terbanyak dari hal-hal yang mejadi pertimbangan konsumen.

\section{METODE PENELITIAN}

\section{Objek dan Lokasi}

Objek dalam penelitian ini adalah konsumen yang pernah membeli roti di toko roti Virgin daerah Telogosari Semarang. Lokasi dalam penelitian ini adalah di toko roti Virgin daerah Telogosari Semarang. Menurut Subagyo dan Djarwanto (2010) populasi adalah kelompok individu yang mempunyai kesamaan karakteristik. Karakteristik ini yang nantinya akan digunakan peneliti untuk penelitian. Populasi dalam penelitian ini adalah seluruh konsumen yang pernah membeli roti di toko roti Virgin Telogosari Semarang, dan jumlah populasi tidak diketahui karena populasi tidak tetap.

Menurut Sekaran (2006) sampel adalah sebagian dari populasi namun tidak semua elemen populasi membentuk sampel. Dalam penelitian ini yang menjadi sampel adalah sebagian konsumen yang pernah membeli di toko roti Virgin yang ada di Telogosari Semarang. Jumlah sampel dalam penelitian ini adalah sebanyak 70 responden. Jumlah sampel ditentukan dengan mempertimbangkan beberapa faktor, seperti waktu penelitian, biaya penelitian, dan kesediaan responden dalam menjawab kuesioner yang diajukan, serta jawaban yang nantinya akan dianggap menoton sehingga pencarian responden dihentikan, dan sudah termasuk melebihi standart minimal pengambilan sampel yaitu 30 responden (Sugiyono, 2010).Teknik sampling yang digunakan dalam penelitian ini adalah purposive sampling dimana pengambilan sampel tersebut di dasarkan pada kriteria tertentu. Adapun kriteria sampel dalam penelitian ini adalah konsumen yang pernah membeli dan sedang membeli di Toko Virgin Telogosari Semarang. 
JEMAP: Jurnal Ekonomi, Manajemen, Akuntansi, dan Perpajakan ISSN: 2622-612X (Media Online) | Vol.2 | No.2 | Oktober 2019

Teknik pengumpulan data yang digunakan dalam penelitian ini adalah dengan membagikan kuesioner. Menurut Sugiyono (2014) kuesioner merupakan teknik pengumpulan data yang dilakukan dengan cara memberi seperangkat pertanyaan atau pertanyaan tertulis kepada responden untuk dijawab. Dalam proses penyebaran kuesioner, tahap yang dilakukan peneliti adalah: Mencari respon dengan cara menunggu di sekitar pintu keluar toko roti Virgin. Menanyai kesediaan responden untuk mengisi kuisoner yang ada pada saat itu di tempat itu juga, dan menjelaskan maksud dari penyebaran kuisoner tersebut. Tanpa melakukan pemaksaan agar hasil yang diperoleh maksimal. Mendampingi responden untuk menyelesaikan dalam menjawab kuesioner yang diberikan. Mengucapkan terimakasih dan menjelaskan kepada responden bahwa data yang diperoleh akan digunakan hanya untuk penelitian ini saja.

Pada penelitian ini, peneliti melakukan analisis diskriptif yaitu analisa yang didasarkan pada jawaban-jawaban dari responden mengenai hal-hal yang berkaitan dengan faktor-faktor yang mempengaruhi keputusan konsumen roti Virgin yang ada di daerah Tlogosari Semarang. Yang kemudian dikelompokan dengan tabeltabel yang sesuai. Ada pun pengelompokan di menurut jawaban yang serupa, kemudian sebagai langkah akhir alat analisis adalah menginterpretasikan data-data dari tabel tersebut.

\section{HASIL PENELITIAN DAN PEMBAHASAN}

\section{Sejarah Umum Virgin Cake \& Bakery}

Toko roti Virgin di Kota Semarang terletak di Jalan Parang Kusumo Raya No.16-17 Tlogosari Kulon Semarang, Jawa Tengah. Dari garasi, Virgin Cake \& Bakery kini menjelma menjadi besar dan memiliki beberapa cabang. Berdiri tahun 1999, berhasil berkembang dengan 250 karyawan dan omset 50 juta rupiah per hari. (http://pakaroti.com/post/trend-update/news/virgin-bakery-andalkan-promosidari-mulut-ke-mulut, 2018) 
JEMAP: Jurnal Ekonomi, Manajemen, Akuntansi, dan Perpajakan ISSN: 2622-612X (Media Online) | Vol.2 | No.2 | Oktober 2019

\section{Gambaran Umum Responden}

Berdasarkan hasil tabulasi data penelitian, terlihat bahwa konsumen toko roti Virgin Tlogosari didominasi oleh konsumen perempuan sebanyak 72,9 \%. Dari jumlah ini yang paling banyak berusia 26 - 30 tahun yaitu sebesar 42,9\%. Konsumen laki- laki ada sebanyak 27,1\%. Berdasarkan usia sebagian besar berusia kurang dari 30 tahun (11 atau 15,7\%) dan lebih dari 50 tahun (5 atau 7,1\%).

Konsumen toko roti Virgin Tlogosari didominasi konsumen yang berusia 26 - 30 tahun dengan pembelian antara Rp 50.000 - Rp 100.000 dalam sekali pembeliannya, yaitu sebasar 28,6\%. Dan yang pembeliannya Rp 20.000 - Rp 50.000 sebesar $38,6 \%$ berusia kurang dari 30 tahun, masing- masing $12,9 \%$ berusia kurang dari 25 tahun dan 10,0\% usia 26- 30 tahun.

Responden berdasarkan Pekerjaan dan Pendidikan didominasi oleh responden yang mempunyai pendidikan $\mathrm{S} 1$ yaitu sebanyak $78,6 \%$ sisanya berpendidikan SMA $(11,4 \%)$ dan S2 (10,0\%). Dengan yang berpendidikan S1, mayoritas bekerja sebagai pegawai swasta sebanyak 51,4\%. Responden toko roti Virgin terbanyak dengan pembelian 4-6 roti sekali transaksi dengan kisaran Rp 20.000 - Rp 50.000 per pembelian dengan pembelian 7-9 roti sekali transaksi dengan kisaran Rp 50.000 - Rp 100.000 per pembelian, masing- masing sebanyak $38,6 \%$. Ada sebanyak 21,4\% konsumen melakukan pembelian di atas 10 buah roti dengan nilai pembelian di atas Rp 100.000 dalam sekali transaksi.

Tabel 4 Responden berdasarkan Rupiah pembelian dan Jumlah Roti

\begin{tabular}{|c|c|c|c|c|c|c|}
\hline & & & \multicolumn{3}{|c|}{ Jumlah_roti } & \multirow[b]{2}{*}{ Total } \\
\hline & & & $\begin{array}{c}\text { 4-6 } \\
\text { buah }\end{array}$ & 7-9 buah & $\begin{array}{l}>10 \\
\text { buah }\end{array}$ & \\
\hline \multirow[t]{6}{*}{ Rupiah_Pembelian } & \multirow{2}{*}{$\begin{array}{l}\text { Rp } 20.000-\mathrm{Rp} \\
50.000\end{array}$} & Jumlah & 27 & 0 & 0 & 27 \\
\hline & & $\%$ total & $38.6 \%$ & $0.0 \%$ & $0.0 \%$ & $38.6 \%$ \\
\hline & \multirow{2}{*}{$\begin{array}{l}\text { Rp } 50.000 \text { - Rp } \\
100.000\end{array}$} & Jumlah & 1 & 27 & 0 & 28 \\
\hline & & $\%$ total & $1.4 \%$ & $38.6 \%$ & $0.0 \%$ & $40.0 \%$ \\
\hline & \multirow[t]{2}{*}{ > Rp 100.000} & Jumlah & 0 & 0 & 15 & 15 \\
\hline & & $\%$ total & $0.0 \%$ & $0.0 \%$ & $21.4 \%$ & $21.4 \%$ \\
\hline \multirow[t]{2}{*}{ Total } & & Jumlah & 28 & 27 & 15 & 70 \\
\hline & & $\%$ total & $40.0 \%$ & $38.6 \%$ & $21.4 \%$ & $100.0 \%$ \\
\hline
\end{tabular}

Sumber : Data primer yang diolah, 2018 
JEMAP: Jurnal Ekonomi, Manajemen, Akuntansi, dan Perpajakan ISSN: 2622-612X (Media Online) | Vol.2 | No.2 | Oktober 2019

\section{Faktor- faktor yang mempengaruhi pembelian roti}

Dari tabel 5 dapat disimpulkan bahwa dari 70 responden terdapat 22 faktor yang mempengaruhi konsumen membeli di toko roti Virgin Cake \& Bakery Tlogosari Semarang. Dari faktor- faktor tersebut faktor tempat terjaga kebersihannya yang paling banyak disebut oleh responden dan mendapat 26 frekuensi sehingga menjadikannya faktor utama sebagai bahan pertimbangan pembelian konsumen di tokot roti Virgin cake \& Bakery Tlogosai Semarang.

Tabel 5 Faktor-Faktor Yang Mempengaruhi Responden Membeli Di Toko Roti Virgin Tlogosari

\begin{tabular}{|c|c|c|}
\hline No & Faktor & Frekuensi \\
\hline 1 & Tempat terjaga kerbersihannya & 26 \\
\hline 2 & Harga terjangkau semua kalangan & 23 \\
\hline 3 & Pegawai ramah & 20 \\
\hline 4 & Teman & 20 \\
\hline 5 & Beraneka ragam jenis produknya & 16 \\
\hline 6 & Tidak terlalu jauh & 16 \\
\hline 7 & Produk selalu baru dari oven & 13 \\
\hline 8 & Palayanan cepat & 13 \\
\hline 9 & Tekstur roti yang lembut & 10 \\
\hline 10 & Murah & 9 \\
\hline 11 & Rasa roti enak & 9 \\
\hline 12 & Ada tanggal kada luasa & 7 \\
\hline 13 & Mudah dicari & 7 \\
\hline 14 & Ada label halal & 6 \\
\hline 15 & Pegawai tanggap & 6 \\
\hline 16 & Saudara & 6 \\
\hline 17 & Terjangkau oleh trasportasi umum & 4 \\
\hline 18 & Tempat parkir luas & 4 \\
\hline 19 & Pengemasan rapi & 3 \\
\hline 20 & Ada informasi kandungan gizi & 3 \\
\hline 21 & Orang tua & 2 \\
\hline 22 & Pasangan & 3 \\
\hline
\end{tabular}

Sumber : Data primer yang diolah, 2018

Sedangkan faktor harga terjangkau semua kalangan mendapat 23 frekuensi, yang menjadikannya faktor urutan kedua setelah faktor tempat terjaga 
JEMAP: Jurnal Ekonomi, Manajemen, Akuntansi, dan Perpajakan ISSN: 2622-612X (Media Online) | Vol.2 | No.2 | Oktober 2019

kebersihannya. Yang ketiga adalah faktor pegawai ramah dan faktor teman yang sama- sama mendapat 20 frekuensi dari responden. Ke 22 faktor tersebut, keempat faktor ini lah yang paling banyak disebut oleh responden, sehingga keempat faktor ini dinilai menjadi faktor penting dalem mempengaruhi keputusan pembelian konsumen di toko roti Virgin Cake \& Bakery. Dari keempat faktor ini juga dapat disimpulkan bahwa rasa roti atau produk bukan menjadikan faktor utama konsumen dalam membeli, dan harga di Virgin Cake \& Bakery di nilai sudah cukup terjangkau di semua kalangan pembeli.

Sedangkan ada juga beberapa faktor yang menjadi keputusan pembelian konsumen akan tetapi dinilai kurang penting dikarenakan sedikitnya responden yang menyebutkan faktor tersebut menjadi keputusan pembeliannya. Adapun beberapa faktor tersebut seperti faktor pengemasan rapi, faktor ada informasi kandungan gizi , faktor orang tua, ketiga faktor tersebut masing- masing mendapat 3 frekuensi dari responden. Dan faktor pasangan mendapat 2 frekuensi yang menjadikan faktor pasangan sebagai faktor terakir dan sekaligus terendah.

Ke 22 faktor- faktor yang mempengaruhi keputusan pembelian konsumen tersebut dikelompokan menjadi beberapa kelompok yang serupa yaitu harga, produk, lokasi, layanan, dan sumber informasi. Hal ini dapat kita lihat pada Tabel 6. Dari faktor- faktor yang terlah dikelompokan, produk merupakan faktor tertinggi yang di pilih responden untuk mempengaruhi keputusan pembelian di toko roti Virgin Telogosari sebesar 67 frekuensi, sedangkan faktor pelayanan mendapat urutan kedua sebesar 65 frekuensi, faktor harga pada urutan ketiga sebesar 32 frekuensi, dan lokasi 31 frekuensi pada urutan keempat, dan yang terakir adalah sumber informasi 31 frekuensi pada urutan kelima. 
JEMAP: Jurnal Ekonomi, Manajemen, Akuntansi, dan Perpajakan ISSN: 2622-612X (Media Online) | Vol.2 | No.2 | Oktober 2019

Tabel 4.6 Kelompok Faktor Pembelian dan Persentasenya

\begin{tabular}{|c|c|c|c|}
\hline $\begin{array}{c}\text { Kelompok } \\
\text { Faktor }\end{array}$ & Faktor & Frekuensi & Persen \\
\hline \multirow{9}{*}{ Produk (F2) } & Beraneka ragam jenis produknya & 16 & 23,88 \\
\hline & Produk selalu baru dari oven & 13 & 19,40 \\
\hline & Tekstur roti yang lembut & 10 & 14,93 \\
\hline & Rasa roti enak & 9 & 13,43 \\
\hline & Ada tanggal kadaluarsa & 7 & 10,45 \\
\hline & Ada label halal & 6 & 8,95 \\
\hline & Pengemasan rapi & 3 & 4,48 \\
\hline & Ada informasi kandungan gizi & 3 & 4,48 \\
\hline & Jumlah & 67 & 100 \\
\hline \multirow{5}{*}{$\begin{array}{l}\text { Pelayanan } \\
\text { (F4) }\end{array}$} & Tempat terjaga kebersihannya & 26 & 40 \\
\hline & Pegawai ramah & 20 & 30,77 \\
\hline & Pelayanan cepat & 13 & 20 \\
\hline & Pegawai tanggap & 6 & 9,23 \\
\hline & Jumlah & 65 & 100 \\
\hline \multirow{3}{*}{ Harga $(\mathrm{F} 1)$} & Harga terjangkau semua kalangan & 23 & 71,87 \\
\hline & Murah & 9 & 28,13 \\
\hline & Jumlah & 32 & 100 \\
\hline \multirow{5}{*}{ Lokasi (F3) } & Tidak terlalu jauh & 16 & 51,61 \\
\hline & Mudah dicari & 7 & 22,58 \\
\hline & Tempat parkir luas & 4 & 12,90 \\
\hline & Terjangkau oleh transportasi umum & 4 & 12,90 \\
\hline & Jumlah & 31 & 100 \\
\hline \multirow{5}{*}{$\begin{array}{c}\text { Sumber } \\
\text { informasi (F5) }\end{array}$} & Teman & 20 & 64,52 \\
\hline & Saudara & 6 & 19,35 \\
\hline & Orang tua & 3 & 9,68 \\
\hline & Pasangan & 2 & 6,45 \\
\hline & Jumlah & 31 & 100 \\
\hline
\end{tabular}

\section{Faktor Produk}

Dari 70 responden ternyata faktor produk yang paling dominan adalah beraneka ragam jenis produk dimana sebanyak 23,88\%. Adapun alasan lain di berikan seperti produk selalu baru dari oven $19,4 \%$, tekstur roti yang lembut $14,93 \%$, rasa roti yang enak $13,43 \%$, mencantumkan tanggal kadaluarsa $10,45 \%$, mencantumkan informasi halal 8,95\%, pengemasan rapi 4,48\%, ada informasi kandungan gizinya 4,48\%. Dari sini dapat disimpulkan sebagian besar kelompok 
JEMAP: Jurnal Ekonomi, Manajemen, Akuntansi, dan Perpajakan ISSN: 2622-612X (Media Online) | Vol.2 | No.2 | Oktober 2019

faktor produk yang mempengaruhi konsumen adalah beraneka ragam jenis produknya dan produk selalu baru dari oven sehingga kualitas produk pun terjamin

Produk-produk andalan dari Virgin Cake \& Bakery di antaranya, berbagai aneka jenis cake cheese cake, steam cake, dan banana cheese cake. Untuk jenis bakery terdapat roti cokelat kenari, roti sunny bun, roti telur kismis, roti keju manis, dan lain sebagainya. Sementara untuk jenis kue kering, antara lain seperti banana cookies, pumpkin cookies, kripik tempe cookies, dan ulat sutra. Sedangkan jenis kue tradisional yang paling banyak dicari adalah lumpia Hongkong, pastel basah, moaci, tahu bakso udang, arem kombinasi, resoles telur asin, dan wingko. Aneka ragam produk dari Virgin Cake \& Bakery jga terlihat dari gambar 1.
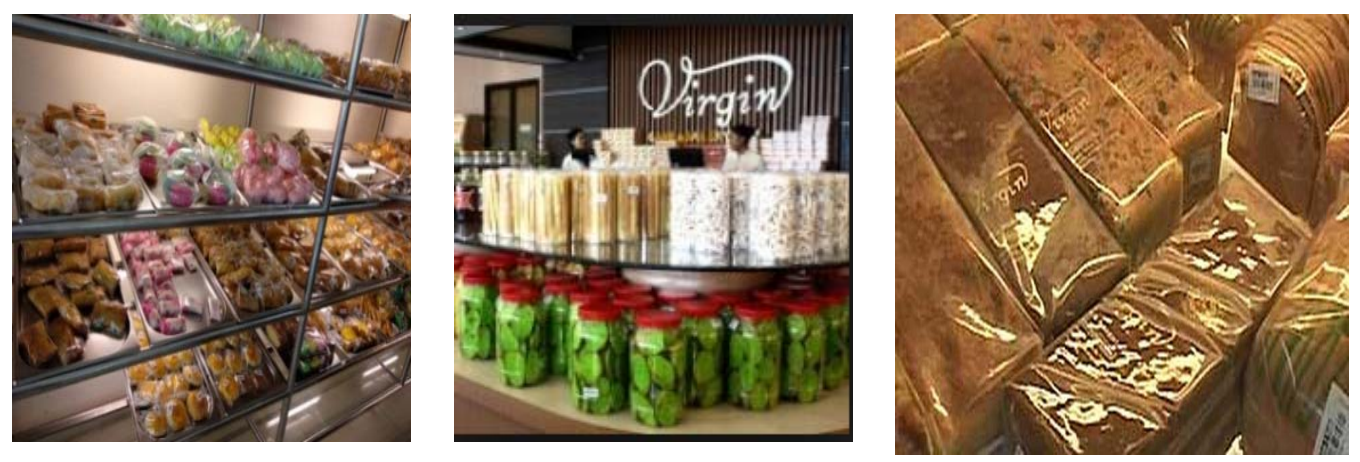

Gambar 1. Aneka Macam produk Virgin Cake \& Bakery

\section{Faktor pelayanan}

Faktor pelayanan adalah faktor kedua yang mempengaruhi konsumen bersedia membeli ditoko roti Virgin Cake \& Bakery Tlogosari Semarang, dimana alasan-alasan yang diberikan responden diantaranya adalah tempat terjaga kebersihannya 40\%, dimana untuk hal kebersihan Virgin Cake \& Bakery sudah menerapkan system sanitasi mulai dari penerimaan bahan baku hingga proses pengemasannya, selain itu dalam gudang penyimpanannya pun Virgin Cake \& Bakery menerapkan system First in First Out yang berfungsi untuk mencegah kadaluarsa bahan baku sebelum digunakan. 
JEMAP: Jurnal Ekonomi, Manajemen, Akuntansi, dan Perpajakan ISSN: 2622-612X (Media Online) | Vol.2 | No.2 | Oktober 2019

Alasan berikutnya adalah pelayanan yang ramah mendapat 30,77\%, pelayanan yang cepat $20 \%$, dan pegawai yang tanggap $9,23 \%$. Adapun pelayanan di Virgin Cake \& Bakery ini dapat dilihat pada gambar 2.
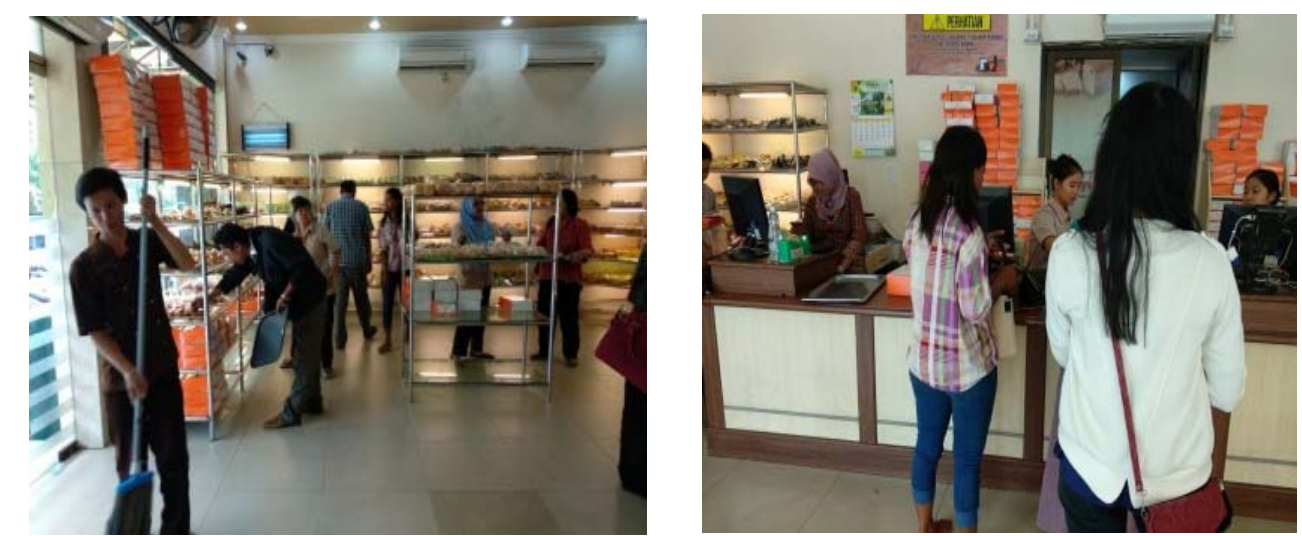

Gambar 2. Pelayanan di Virgin Cake \& Bakery Tlogosari

\section{Faktor harga}

Terdapat dua faktor yang yang dapat dikategorikan ke dalam faktor harga. Yang pertama adalah 'harga terjangkau semua kalangan' dan 'murah'. Harga dari produk Virgin Cake \& Bakery masih bias terbilang terjangkau oleh semua kalangan ekonomi, mulai dari Rp 1.500 - Rp 35.000. Faktor harga merupakan faktor ketiga yang mempengaruhi konsumen membeli di Virgin Cake \& Bakery, dimana ada $71,87 \%$ i yang menyatakan bahwa faktor harga terjangkau semua kalangan dan $28,13 \%$ menyatakan harga murah. Dari sini dapat di simpulkah bahwa responden toko roti Virgin Cake \& Bakery Tlogosari Semarang menganggap harga roti sudah terjangkau semua kalangan walaupun belum tentu murah.

\section{Faktor lokasi}

Faktor lokasi ini merupakan salah satu faktor yang mempengaruhi responden dalam memilih Virgin Cake \& Bakery, dimana diantarnya ada 51,61\% menyatakan bahwa lokasi toko roti Virgin tidak terlalu jauh, 22,58\% menyatakan lokasinya mudah dicari, 12,9\% menyatakan bahwa lokasi Virgin Cake \& Bakery terjangkau oleh transportasi umum, dan $12,9 \%$ menyatakan bahwa tempat parkir 
JEMAP: Jurnal Ekonomi, Manajemen, Akuntansi, dan Perpajakan ISSN: 2622-612X (Media Online) | Vol.2 | No.2 | Oktober 2019

yang dimiliki luas dan aman, dimana lahan parkir yang luas ini terlihat dari gambar 3. Dari sini dapat di simpulkan bahwa lokasi toko roti sangat strategis dikarenakan terletak dekat jalan utama Tlogosari dan tidak jauh dari jalan raya jl. Alteri Soekarno Hatta. Selain itu lokasi juga berada di dekat perumahan dan pertokoan yang padat penduduk, serta toko memiliki area parkir yang luas yang memudahkan konsumen untuk parkir dan aman dikarenakan selalu ada 2 satpam yang menjaga di depan parkiran.
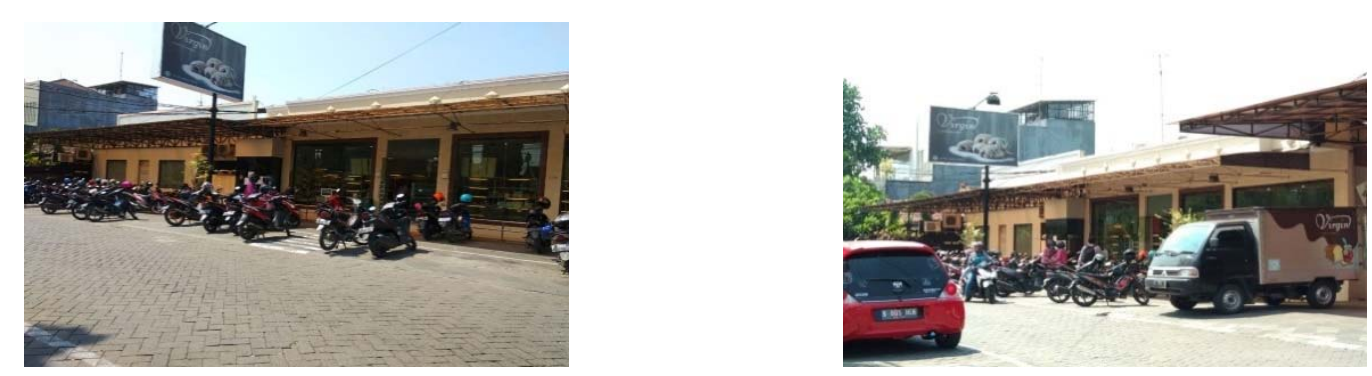

Gambar 3. Lahan Parkir Virgin Cake \& Bakery di Tlogosari yang luas

\section{Faktor sumber informasi}

Faktor sumber informasi merupakan faktor pendukung terakhir yang menentukan konsumen berminat untuk membeli di Toko Roti Virgin ini, yang mana besarnya faktor promosi dalam memperkenalkan toko roti Virgin menyatakan mengetahui Virgin Cake \& Bakery karena direkomendasikan dari orang lain. Rekomendasi dari teman sebanyak 64,52\% merupakan bentuk dari promosi tradisional "mulut lewat mulut" yang paling efektif yang dilakukan Virgin Cake \& Bakery ini karena toko roti Virgin Cake \& Bakery memang tidak memiliki tenaga marketing khusus yang bertugas mempromosikan bisnisnya ataupun melalui iklan dan media massa lainnya. Selanjutnya, promosi serupa juga dilakukan melalui saudara sebanyak $19,35 \%$, orang tua $9,68 \%$, dan pasangan sebanyak $6,45 \%$.

Berdasarkan lima kelompok faktor tersebut, responden diminta memberikan alasan-alasan juga mengapa memilih membeli roti di Virgin Cake \& Bakery Tlogosari. Dari lima faktor yang mempengaruhi konsumen membeli di Virgin Cake \& Bakery. 
JEMAP: Jurnal Ekonomi, Manajemen, Akuntansi, dan Perpajakan

\section{KESIMPULAN DAN SARAN}

\section{Kesimpulan}

Dalam penelitian ini ada 22 faktor yang menjadi pertimbangan konsumen dalam membeli roti di Virgin Cake \& Bakery Tlogosari. Namun dari faktor-faktor tersebut tempat terjaga kebersihannya paling di anggap penting dengan frekuensi 26 yang merupakan salah satu dari faktor pelayanan, yang kedua adalah harga terjangkau di semua kalangan dengan 23 frekuensi yang merupakan salah satu faktor harga, dan urutan ketiga dan keempat adalah pegawai ramah yang termasuk faktor pelayanan dan teman termasuk faktor sumber informasi yang masingmasing mendapat 20 frekuensi.

Ke 22 faktor tersebut juga dikelompokan menurut yang serupa sehingga terbentuk lima kelompok faktor yaitu fakor produk, pelayanan, harga, lokasi, dan sumber informasi. Dari lima faktor tersebut faktor produk menjadi faktor yang paling dominat yang medapat total 67 frekuensi, yang kedua pelayanan 65 frekuensi, harga 32 frekuensi, lokasi 31 frekuensi, dan sumber informasi 31 frekuensi

\section{Saran}

Bagi Toko Roti Virgin Cake \& Bakery Tlogosari faktor tempat terjaga kebersihan, harga terjangkau semua kalangan, pegawai ramah, dan teman merupakan faktor dominan yang membuat konsumen mendatangi dan membeli produk-produk Virgin Cake \& Bakery, maka disarankan agar Virgin Cake \& Bakery : untuk tetap menjaga dan mempertahankan kebersihan toko, mulai dari di sekitar toko baik kebersihan parkiran dan halaman, maupun di dalam toko seperti lantai, rak roti, pendingin roti serta meja kasir yang harus selalu d jaga kebersihannya. Selain itu juga menjaga dan mempertahankan harga yang terjangkau semua kalangan karena bagi konsumen harga sangat penting mengingat banyak toko roti pesaing di daerah Telogosari Semarang. Toko Roti Virgin diharapkan tetap mejaga dan mengajarkan agar pegawai selalu ramah, sehingga suasana hati konsumen pada saat belanja roti menjadi baik dan nyaman sehingga konsumen menjadi betah berada di dalam toko roti Virgin. Juga menjaga dan mempertahankan hubungan baik dengan lingkungan sekitar dan konsumen yang 
JEMAP: Jurnal Ekonomi, Manajemen, Akuntansi, dan Perpajakan ISSN: 2622-612X (Media Online) | Vol.2 | No.2 | Oktober 2019

sudah ada sehingga promosi dari mulut kemulut tetap terjaga, karna faktor teman merupakan salah satu faktor yang paling mempengaruhi pembelian konsumen.

\section{DAFTAR PUSTAKA}

Akbar, K. (2013). Analisis Pengaruh Harga, Brand, Image, dan Atribut Produk Terhadap Keputusan Pembelian Handphone Atau Smartphone Samsung Jenis Android. 26.

Andini, P. (2012). Analisis Faktor-Faktor yang Mempengaruhi. Semarang: universitas Diponegoro.

Arianto, A. B. (2013). Pengaruh Atribut Produk, Harga, Kebutuhan Mencari Variasi dan Ketidakpuasan Konsumen terhadap Keputusan Perpindahan Merek dari Samsung Galaxy Series di Kota Malang. Jurnal Aplikasi Manajemen, 297.

Daud, D. (2013). Promosi dan Kualitas Layanan Pengaruhnya Terhadap Keputusan Konsumen. EMBA, 53.

Daud, D. (2013). Promosi dan Kualitas Layanan Pengaruhnya Terhadap Keputusan Konsumen Menggunakan Jasa Pembiayaan Pada PT. Bess Finance Manado. EMBA, 53.

Engel, J. F., Blackwell, R. D., \& Miniard, P. W. (1993). Consumer Behavior. Orlando: The Dry Press.

Ghanimata, F. (2012). Analisis Pengaruh Harga, Kualitas Produk, dan Lokasi Terhadap Keputusan Pembelian. Semarang: Universitas Diponegoro.

Kotler, P. (1986). Menejemen Pemasaran. Jakarta: Erlangga.

Kotler, P. (2005). Manajemen Pemasaran. Jakarta: PT. Indeks Kelompok Gramedia.

Kotler, P., \& Armstrong, G. (2001). Prinsip- Prinsip Pemasaran. Jakarta: Erlangga. Kotler, P., \& Keller, K. L. (2009). Manajemen Pemasaran. Jakarta: Erlangga. 
JEMAP: Jurnal Ekonomi, Manajemen, Akuntansi, dan Perpajakan ISSN: 2622-612X (Media Online) | Vol.2 | No.2 | Oktober 2019

Kotler, P., \& Keller, K. L. (2009). MANAJEMEN PEMASARAN. Jakarta: Erlangga.

Mowen, J. C., \& Minor, M. (2002). Perilaku Konsumen. Jakarta: Erlangga.

eter, J. P., \& Olson, J. C. (2000). Consumer Behavior. Jakarta: Erlangga.

Saidani, B., \& Ramadhan, D. R. (2013). Pengaruh Iklan dan Atribut Produk Terhadap Keputusan Pembelian Smartphone Samsung Seri Galaxy (Survei Pada Pelanggan ITC Roxy Mas). Jurnal Riset Manajemen Sains Indonesia, IV, 58-59.

Sekaran, U. (2006). Metodologi Penelitian untuk Bisnis Jilid 2 Edisi 4. Jakarta: Selemba Empat.

Subagyo, P., \& Djarwanto. (2010). Statistika Induktif. Yogyakarta: BPFE.

Sugiyono. (2008). Metode Penelitian Kuantitatif Kualitatif dan R\&D. Bandung: Alfabeta.

Sugiyono. (2010). Metode Penelitian Bisnis. Alfabeta.

Sugiyono. (2010). Metode Penelitian Bisnis. Bandung: Alfabeta.

Sugiyono. (2014). Metode Penelitian Bisnis. Bandung: Alfabeta.

Utami, C. W. (2014). Manajemen Ritel. Jakarta: Salemba Empat. 